\title{
A Multi-Endpoint Approach to Base Excision Repair Incision Activity Augmented by PARylation and DNA Damage Levels in Mice: Impact of Sex and Age
}

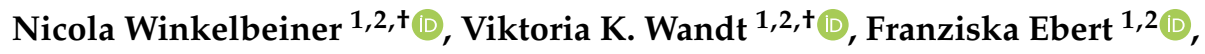 \\ Kristina Lossow ${ }^{2,3,4}$, Ezgi E. Bankoglu ${ }^{5}$, Maximilian Martin ${ }^{1}$, Aswin Mangerich ${ }^{6}(\mathbb{D}$, \\ Helga Stopper ${ }^{5}$, Julia Bornhorst ${ }^{2,7}$, Anna P. Kipp ${ }^{2,3}$ and Tanja Schwerdtle ${ }^{1,2,8, *}$ \\ 1 Department of Food Chemistry, Institute of Nutritional Science, University of Potsdam, \\ Arthur-Scheunert-Allee 114-116, 14558 Nuthetal, Germany; winkelbeiner@uni-potsdam.de (N.W.); \\ vwandt@uni-potsdam.de (V.K.W.); fraebert@uni-potsdam.de (F.E.); martin@igzev.de (M.M.) \\ 2 TraceAge-DFG Research Unit on Interactions of Essential Trace Elements in Healthy and Diseased \\ Elderly (FOR 2558), 14558 Berlin-Potsdam-Jena-Wuppertal, Germany; kristina.lossow@uni-jena.de (K.L.); \\ bornhorst@uni-wuppertal.de (J.B.); anna.kipp@uni-jena.de (A.P.K.) \\ 3 Department of Molecular Nutritional Physiology, Institute of Nutritional Sciences, Friedrich Schiller \\ University Jena, Dornburger Straße 24, 07743 Jena, Germany \\ 4 German Institute of Human Nutrition, Arthur-Scheunert-Allee 114-116, 14558 Nuthetal, Germany \\ 5 Institute of Pharmacology and Toxicology, University of Würzburg, Versbacher Straße 9, 97078 Würzburg, \\ Germany; ezgi.bankoglu@uni-wuerzburg.de (E.E.B.); stopper@toxi.uni-wuerzburg.de (H.S.) \\ 6 Department of Biology, Molecular Toxicology Group, University of Konstanz, Universitätsstraße 10, \\ 78457 Konstanz, Germany; aswin.mangerich@uni-konstanz.de \\ 7 Food Chemistry, Faculty of Mathematics and Natural Sciences, University of Wuppertal, Gaußstraße 20, \\ 42119 Wuppertal, Germany \\ 8 German Federal Institute for Risk Assessment (BfR), Max-Dohrn-Strasse 8-10, 10589 Berlin, Germany \\ * Correspondence: tanja.schwerdtle@uni-potsdam.de; Tel.: +49-33200-885528 \\ + These authors contributed equally to this work.
}

Received: 27 August 2020; Accepted: 7 September 2020; Published: 9 September 2020

\begin{abstract}
Investigation of processes that contribute to the maintenance of genomic stability is one crucial factor in the attempt to understand mechanisms that facilitate ageing. The DNA damage response (DDR) and DNA repair mechanisms are crucial to safeguard the integrity of DNA and to prevent accumulation of persistent DNA damage. Among them, base excision repair (BER) plays a decisive role. BER is the major repair pathway for small oxidative base modifications and apurinic/apyrimidinic (AP) sites. We established a highly sensitive non-radioactive assay to measure BER incision activity in murine liver samples. Incision activity can be assessed towards the three DNA lesions 8-oxo-2'-deoxyguanosine (8-oxodG), 5-hydroxy-2'-deoxyuracil (5-OHdU), and an AP site analogue. We applied the established assay to murine livers of adult and old mice of both sexes. Furthermore, poly(ADP-ribosyl)ation (PARylation) was assessed, which is an important determinant in DDR and BER. Additionally, DNA damage levels were measured to examine the overall damage levels. No impact of ageing on the investigated endpoints in liver tissue were found. However, animal sex seems to be a significant impact factor, as evident by sex-dependent alterations in all endpoints investigated. Moreover, our results revealed interrelationships between the investigated endpoints indicative for the synergetic mode of action of the cellular DNA integrity maintaining machinery.
\end{abstract}

Keywords: maintenance of genomic integrity; ageing; sex; DNA damage; base excision repair (incision activity); DNA damage response; poly(ADP-ribosyl)ation; liver 


\section{Introduction}

The limited chemical stability of DNA under physiological conditions facilitates the constant formation of a broad spectrum of DNA lesions [1]. Remaining unrepaired, DNA lesions can have deleterious consequences, that eventually can cause cancer and accelerate ageing [2]. Nuclear DNA damage accumulation and genomic instability seem to be important drivers in ageing, leading to cellular functional decline or loss of tissue homeostasis [3,4]. To maintain genomic stability, cellular mechanisms including the DNA damage response (DDR) and DNA repair are essential [2,5]. According to the general opinion stated in the literature, DNA damage increases with age, whereas the DNA repair capacity declines with age [5].

The major cellular repair pathway to remove the vast and frequently occurring spectrum of small oxidative base modifications, apurinic/apyrimidinic (AP) sites, and single-strand breaks is base excision repair (BER) (reviewed in [6-10]).

There are different approaches to study BER processes. The predominant approach includes the preparation of a cell or tissue extract that contains the active repair enzymes and is incubated with DNA damage-containing substrates. These can be radioactively or fluorescently labelled oligonucleotides or plasmids with an incorporated DNA lesion, and, in case of comet assay-based repair assays, damaged nucleoid DNA [11-15]. Many extract-based assays monitor specific BER initiating incision events performed by DNA glycosylases [11,12,15]. Also, all further enzymatic steps of BER, such as activities of polymerases and ligases, can be assessed [13-15]. Assays yielding information on the repair process in its entirety are considered as the most comprehensive approach to study BER. The same is true for assays based on host cell reactivation $[16,17]$. However, the application of these assays to tissue samples is still more limited because tissue is a more complex matrix than cultured cells and, in some cases, intact vital cells are required for assay performance.

Within this work, we established a highly sensitive non-radioactive BER incision activity assay to quantify the efficiency of the BER damage incision step in murine liver tissue. The assay's advantage is that BER incision activity can be determined from one single tissue extract for three DNA lesions. To achieve this, we applied oligonucleotides that contain the oxidative base modifications 8-oxodG, 5-OHdU, or an AP site analogue (schematically shown in Figure 1A). 8-oxodG is numerously formed (100-500 times per day in a mammalian cell) because guanine has the lowest oxidation potential among the nucleobases and is therefore particularly vulnerable to reactive oxygen species (ROS) attack [1,18]. Repair of 8-oxodG in mammals is predominantly initiated by the 8-oxoguanine DNA glycosylase 1 (OGG1) [12,19,20]. 5-OHdU is formed by oxidative deamination of cytosine, mostly driven by ROS [21]. It is mainly removed by the nei-like DNA glycosylases 1 and 2 (NEIL1/2), and the nth-like DNA glycosylase 1 (NTH1) [22-25]. The third DNA lesion investigated is an AP site, which is a nucleoside in DNA that has neither a purine nor a pyrimidine base. It can be formed by spontaneous hydrolysis under physiological conditions (approximately 10,000 times per day per human genome) or in the process of BER [1,26]. AP endonuclease 1 (APE1) is the major mammalian enzyme responsible for processing AP sites [27]. All of these DNA lesions are premutagenic [28,29]. If they remain unrepaired, a variety of cellular problems result, and eventually persistent DNA damage can be fixed in mutations, thus contributing to genomic instability [26]. The possibility to analyse the three above-described BER incision events in murine tissue presents a powerful tool to investigate cellular capacity to recognize specific DNA lesions and initiate DNA repair.

Next to DNA repair, the DDR fulfils a crucial function within the cellular response to incurred DNA damage by mediating the initialization of repair processes and recruiting the respective repair enzymes. Outstanding in its versatile physiological functions, among others in the DDR and BER, is the multi-functional enzyme family of poly(adenosine diphosphate (ADP)-ribose) polymerases (PARPs). PARPs serve as damage sensor, initiate and support BER, and facilitate DNA accessibility to the respective repair enzymes [30]. The enzymes catalyse the transient post-translational modification of proteins with poly(ADP-ribose) (PAR) in response to genotoxic insults such as DNA strand breaks, a process referred to as PARylation. During PARylation, linear or branched ADP-ribose chains of up to 
200 ADP-ribose units are formed that affect acceptor protein function due to the negative charge of the ADP-ribose polymer [31]. As fast as PAR is formed in response to DNA damage, as rapidly it is degraded by the poly(ADP-ribose) glucohydrolase and the PAR hydrolase 3 [32,33]. In vitro studies showed that PARylation promotes recovery from genotoxic stress [34]. While efficient PARylation is thought to delay ageing, PARP1 deficiency has been shown to facilitate ageing $[35,36]$. To assess the tissue PARylation status, we quantified cellular PAR in the mouse livers via stable isotope dilution liquid chromatography tandem mass spectrometry (LC-MS/MS) [37].

A

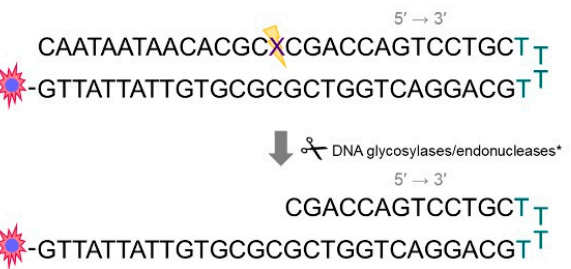

B
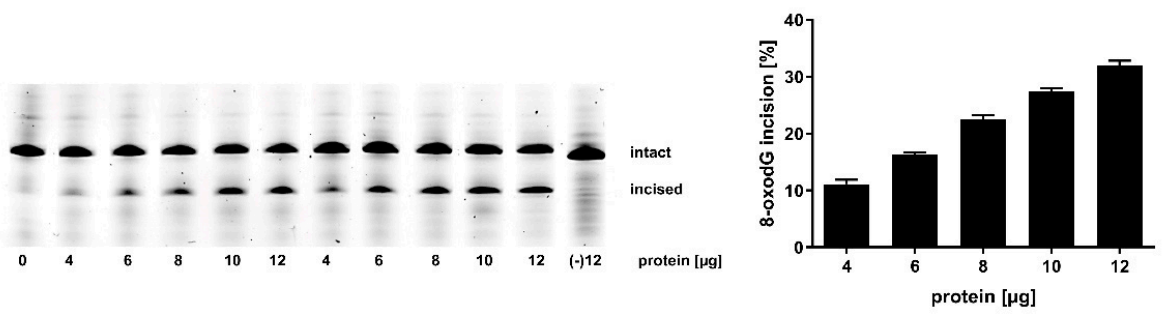

c

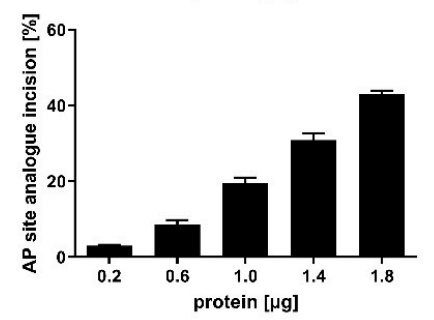

D
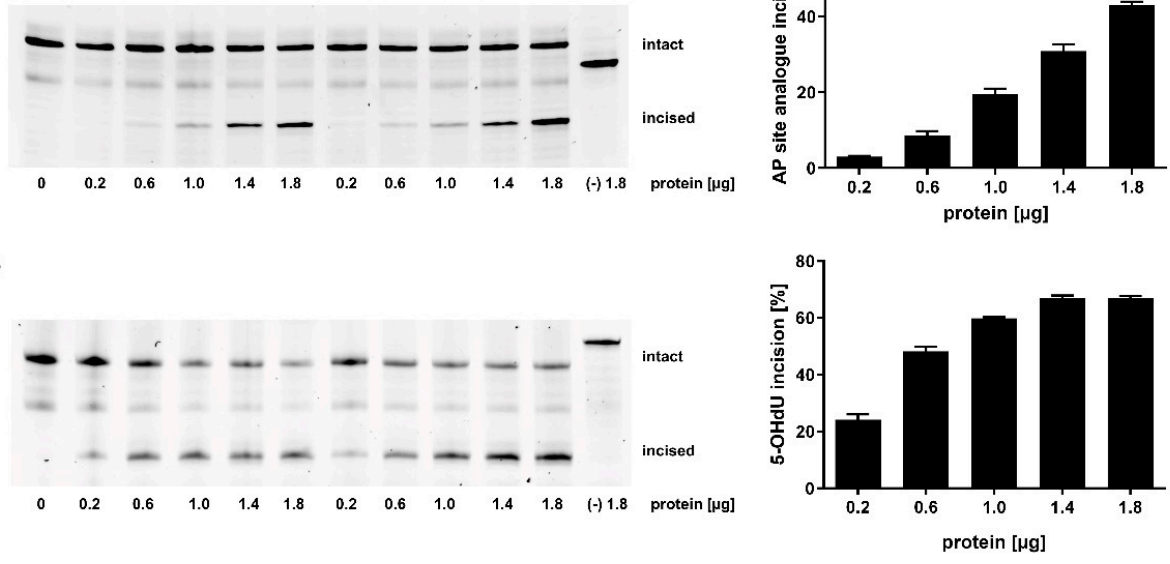

Figure 1. Incision activity assay. Schematically shown is the 3' Cy5-labelled oligonucleotide base sequence of the 8-oxodG/ AP site analogue containing oligonucleotide in hairpin structure (5-OHdU containing oligonucleotide slightly differing) before and after lesion incision (A). Major relevant DNA glycosylases/endonucleases ${ }^{*}$ ) for lesion $(X)$ incision: $X=8$-oxodG $\rightarrow$ OGG1 (+ APE1), $X=$ AP site analogue $\rightarrow$ APE1, $X=5-\mathrm{OHdU} \rightarrow \mathrm{NEIL1} / 2$ (+ polynucleotide kinase) / NTH1 (+ APE1). Incision activity of different amounts of tissue extract protein was assessed towards (B) the 8-oxodG, (C) the AP site analogue, and (D) the 5-OHdU containing oligonucleotide by fluorescence detection (full-length gels are shown in Figure S3). Shown are polyacrylamide gels (left, 2 replicates of each applied protein amount are shown) and mean values $+\operatorname{SEM}(n=4$ (technical replicates of one animal)) of corresponding quantified BER incision activity (right). Quantification was performed by analysis of percentage of incised (lower band) versus intact (upper band) oligonucleotide for each lane. As negative control for each oligonucleotide with a DNA lesion, a damage-free oligonucleotide with the respective base sequence and the correct pairing base ( $\mathrm{G}$ instead of 8-oxodG and the AP site analogue; $\mathrm{C}$ instead of 5-OHdU; marked as (-)) was designed and incubated according to the assay protocol with tissue extract protein. 
Further, the analysis of DNA damage levels can give an indication on the integrity of the cellular DNA and is directly related to the fidelity of DDR and DNA repair. DNA damage imbalances tissue homeostasis and is discussed as a central cause and consequence of ageing and age-related disease (reviewed in [3]). Among the highly diverse myriad of DNA damage types associated with ageing, including DNA strand breaks, cross-links, and (oxidative) base modifications, DNA single- and double-strand breaks, as well as AP sites can for example be assessed by alkaline comet assay $[2,5,38]$. This single cell gel electrophoresis is a standard method frequently used in genotoxicity testing and biomonitoring, convincing by its sensitivity, simplicity, and reproducibility $[38,39]$. Compared to other methods used to quantify DNA damage, for example via LC/MS-MS, only a small amount of tissue is needed for assay performance and obtained results are on the level of individual cells [38]. Yet, via highly sensitive LC-MS/MS analysis, also specific complex DNA lesions, relevant to ageing, can be targeted, which are not accounted for by comet assay analysis [40].

Innovative and feasible methods to analyse the efficiency of the cellular response to DNA damage represent valuable tools in basic research and in the assessment of potential benefits and risks, for example in development and targeting of drugs. By the combined assessment of BER incision activity, the PARylation status, and DNA damage levels in the liver of adult and old mice of both sexes, this paper aims to contribute to a deeper understanding of the impact of age and sex on the genomic stability maintaining machinery.

Within this study, reliable methods for the analysis of the cellular DDR and DNA repair status in murine liver were established and validated. Implementation of the described methods revealed no significant impact of ageing on the assessed endpoints. Yet, animal sex evidently affected BER incision activity, PARylation, and DNA damage levels. Further, our results revealed predictive relationships between DNA damage level and PARylation as well as between DNA damage level and BER incision activity.

\section{Results}

\subsection{Adaption of Assay Parameters}

To prepare a suitable tissue extract for the incision assay, we adapted different parameters of the cell-based protocol [12]. We added the non-ionic surfactant Triton X-100, known to improve cellular membrane permeability [41], in a final concentration of $1 \%$ to the extraction buffer. This enhances the release of the soluble protein fraction from the tissue-bound liver cells that have a more complex matrix than cultured cells. Besides the extraction buffer from the cell-based protocol, we tested a 4-(2-hydroxyethyl)piperazine-1-ethanesulfonic acid (HEPES)-based extraction buffer, which was reported to be efficient in a comet-based DNA repair assay [42]. Eventually, incision activity was reduced applying the HEPES-based extraction buffer (Figure S1A, buffer B). Thus, we chose the extraction buffer from the cell-based incision assay (Figure S1A, buffer A). Assays to determine DNA repair activity in extracts from rodent tissues have been reported to be susceptible to disturbance by non-specific nuclease activity [42-44]. Langie et al. showed that the addition of $1.5 \mu \mathrm{M}$ aphidicolin (APC) to tissue extracts could reduce non-specific nuclease activity, while DNA repair incision activity could be improved in a comet-based in vitro repair assay [42]. Therefore, we included $1.5 \mu \mathrm{M}$ APC in our extraction buffer. Homogenization of the liver tissue was performed in the optimized extraction buffer using a bead ruptor and zirconia beads. We added $1 \mathrm{~mL}$ of extraction buffer to $50 \mathrm{mg}$ of frozen liver tissue to obtain optimal protein concentrations $(7-10 \mathrm{mg} / \mathrm{mL})$. This ensured best storage stability and handling of the tissue extract in the assay procedure. Interestingly, we found that the centrifugation step with $10 \mathrm{kDa}$ filter units previously used for cell extracts is not needed for murine liver extracts (Figure S1B). Finally, we quantified fluorescence of the fluorophore with high sensitivity in the fmol range, applying a charge-coupled device (CCD)-camera based imaging system with LEDs as light source. 


\subsection{Optimal Protein Amounts, Storage Conditions, and Tissue Processing}

According to the adapted protocol, tissue extracts from murine liver were prepared and the optimal protein amount was determined for each of the three damage-containing oligonucleotides. In this case, the optimal protein amount is characterized by the degree of incision activity. It should allow to detect an increase as well as a decrease in incision activity to make the assay capable of showing changes in incision activity in both directions. Based on the results for the 8-oxodG containing oligonucleotide, $8 \mu \mathrm{g}$ tissue extract protein were chosen, whereas for the AP site analogue and 5-OHdU containing oligonucleotides, $1 \mu \mathrm{g}$ of tissue extract protein appeared to be most suitable. Applying these protein amounts resulted in incision activities within a linear range, therefore meeting the assay criteria described above. Differences in incision activity levels refer to enzyme activities under assay conditions. To ensure quantification of only specific incision events, we incubated damage-free oligonucleotides with the respective base sequences, but with an intact pairing base with tissue extract. The control samples showed that no unspecific incision occurred and that the oligonucleotides were stable under assay conditions (Figure 1B-D).

Incision activity of tissue extracts was not affected by storage at $-80^{\circ} \mathrm{C}$ for $24 \mathrm{~h}$ or five days. Nevertheless, storing extracts at $4{ }^{\circ} \mathrm{C}$ or $-20^{\circ} \mathrm{C}$ resulted in a dramatic decrease of incision activity, especially after five-day storage at $4{ }^{\circ} \mathrm{C}$ (Figure 2A-C). Additionally, incision activity was compared with regard to long-term storage. Hence, liver tissue extracts of two different mice were prepared from liver that was stored at $-80^{\circ} \mathrm{C}$ only for a few days or three months. Incision activity of the freshly prepared tissue extracts was compared to incision activity of the three months at $-80^{\circ} \mathrm{C}$ stored tissue extracts and to incision activity of tissue extracts prepared from the three months at $-80^{\circ} \mathrm{C}$ stored liver tissue (Figure 2D-F). Examination of incision activity revealed that the intact liver tissue and the prepared tissue extracts can be stored for three months at $-80^{\circ} \mathrm{C}$ without remarkably affecting incision activity. Furthermore, we tested if tissue treatment prior to preparation of tissue extracts impacts on incision activity. Thus, a small piece of tissue was either frozen in liquid nitrogen (directly after harvesting) and kept at $-80^{\circ} \mathrm{C}$ until preparation of tissue extract, or it was frozen by squeezing it between two liquid nitrogen cooled stainless steel plates. The squeezed liver tissue was further used in this form for preparation of tissue extract or was additionally homogenized under liquid nitrogen cooling with mortar and pestle. Best results were obtained by preparing tissue extracts from tissue directly frozen after harvesting without any tissue treatment (data not shown).

A
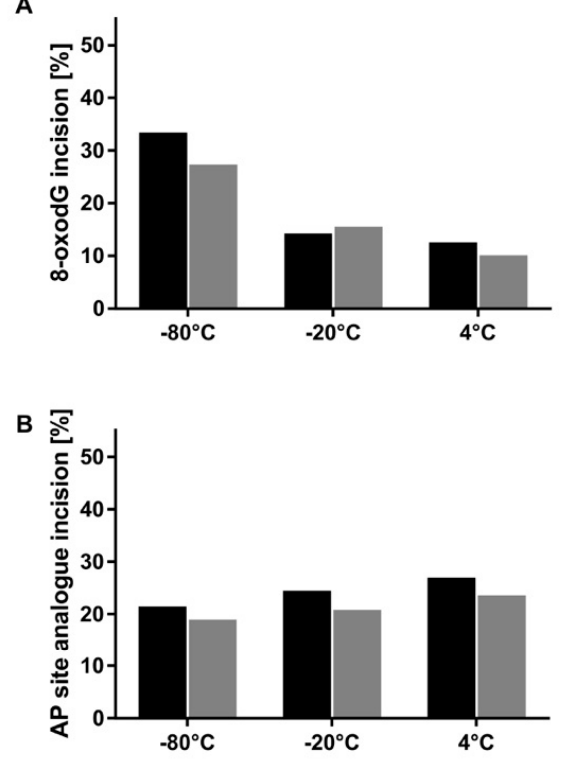

D
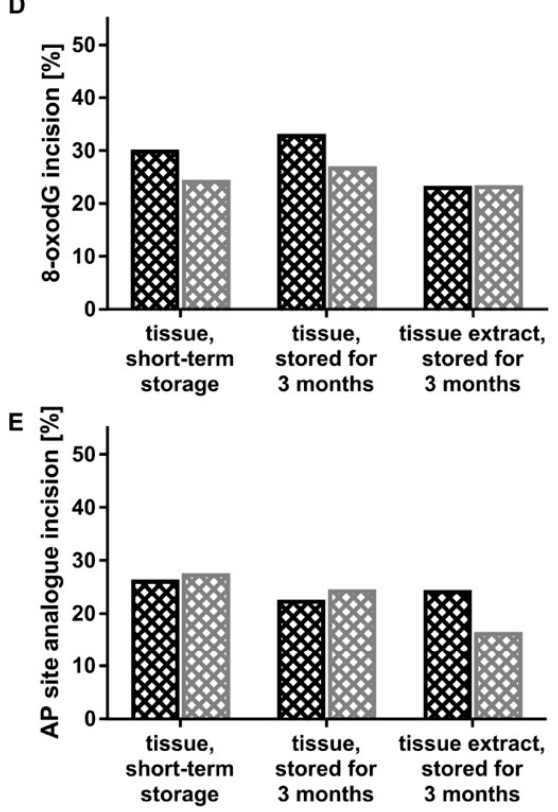

Figure 2. Cont. 

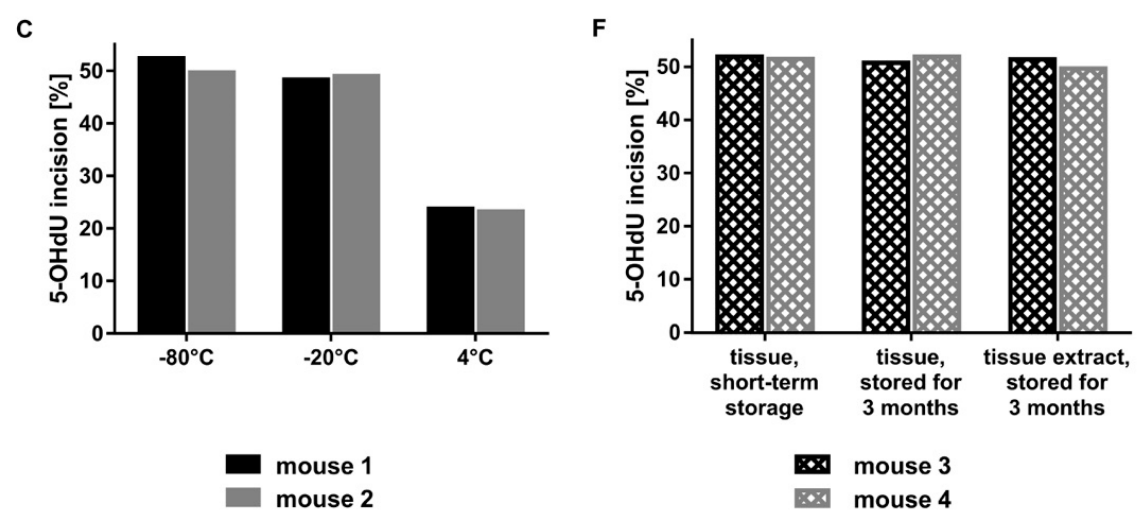

Figure 2. Storage stability. For assessment of short-term storage stability of murine liver extracts, incision activity was determined towards (A) the 8-oxodG, $(\mathbf{B})$ the AP site analogue, and $(\mathbf{C})$ the 5 -OHdU containing oligonucleotide after 5-day storage of liver tissue extracts at $-80,-20$, or $4{ }^{\circ} \mathrm{C}$. Tissue extract protein amounts of two different mice were applied as follows: $6 \mu \mathrm{g}$ for the 8-oxodG, $1 \mu \mathrm{g}$ for the AP site analogue and 5-OHdU containing oligonucleotide. Regarding long-term storage stability, incision activity was determined towards the (D) 8-oxodG, (E) AP site analogue, and (F) 5-OHdU containing oligonucleotide after short-term (max. 5 days) or long-term storage ( 3 months) of liver tissue or after long-term storage ( 3 months) of tissue extracts. Tissue extract protein amounts of two different mice were applied as follows: $8 \mu \mathrm{g}$ for 8-oxodG, $1 \mu \mathrm{g}$ for the AP site analogue and 5-OHdU.

\subsection{Application of the Incision Activity Assay to a Cohort of Adult and Old Mice}

The established incision activity assay was applied to study age and sex effects on incision activity in a group of 19 mice of both sexes that were fed with a standard chow and were either 24 weeks (adult, $n=10$ ), or 109-114 weeks old (old, $n=9$ ). Incision activity towards the 8-oxodG containing oligonucleotide was mainly between 20 and 30\% for most of the animals (Figure 3A). Mean incision activity within the groups of adult ( $24.21 \pm 1.85 \%$ incision) and old animals $(23.55 \pm 1.48 \%$ incision) showed no significant differences. Incision activity regarding the AP site analogue containing oligonucleotide was $20 \%$ for the majority of animals, with some animals showing increased or decreased incision activities in both age groups (Figure 3B). As for the 8-oxodG containing oligonucleotide, we did not observe age-related differences in the mean incision activity (adult mice: $21.05 \pm 5.29 \%$ incision; old mice: $20.94 \pm 1.51 \%$ incision). Mean incision activity towards the 5 -OHdU containing oligonucleotide was $50-60 \%$ incision on average with a tendency to be higher in old animals ( $53.12 \pm 3.35 \%$ incision) than in adults ( $51.33 \pm 2.34 \%$ incision) (Figure 3C). Interestingly, for 5-OHdU we observed a significant sex-specific difference in mean incision activity that did not manifest for the 8-oxodG or AP site analogue containing oligonucleotides (Figure 3D-F). Male animals showed a significantly higher mean incision activity towards the 5-OHdU containing oligonucleotide than females (male: $54.15 \pm 2.26 \%$ incision; female: $50.40 \pm 2.27 \%$ incision). In Figure A1A-C, results are shown differentiated for sex and age of the mice at the same time. Representative gels of the sample measurements for each of the three oligonucleotides are shown in Figure 3G-I.

\subsection{Determination of Parylation Levels in Murine Liver}

Mean PARylation levels in the livers of the studied animals were in general between 2 and 8 pmol $\mathrm{PAR} / \mathrm{mg}$ DNA and did not differ strongly between adult (5.25 $\pm 0.56 \mathrm{pmol} \mathrm{PAR} / \mathrm{mg}$ DNA) and old mice (5.55 $\pm 0.34 \mathrm{pmol}$ PAR/mg DNA) (Figure 4A). Remarkably, PARylation levels within the group of adult animals showed a higher variation compared to the more consistent PARylation levels within the group of the old animals. Though, sex-specific differences became apparent for the PARylation levels. Female mice showed significantly higher mean PARylation levels $(6.04 \pm 0.38$ pmol PAR/mg DNA) than male animals (4.67 $\pm 0.45 \mathrm{pmol}$ PAR/mg DNA) (Figure 4B). In Figure A1D, results are shown differentiated for sex and age of the mice at the same time. 

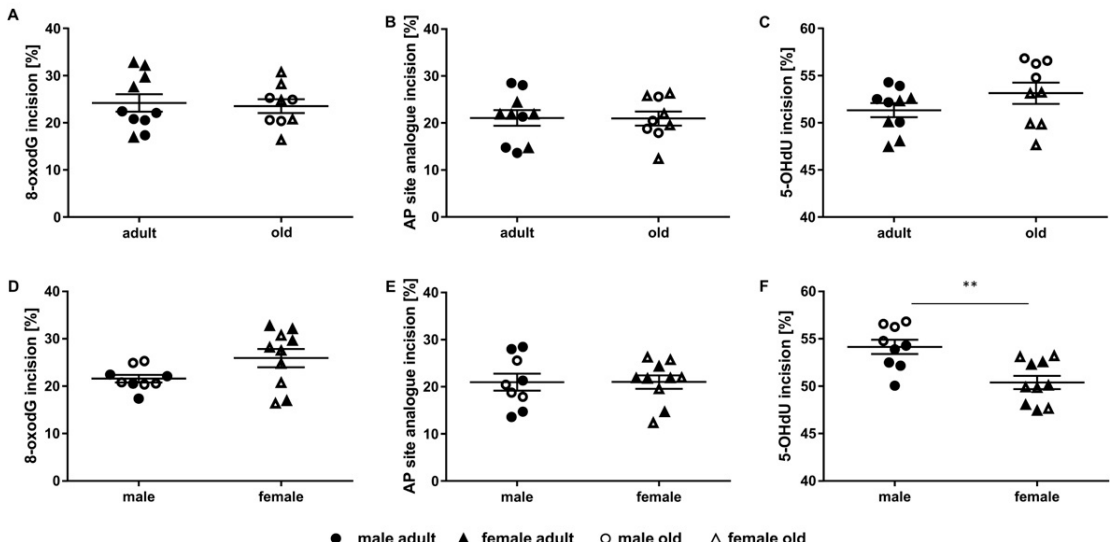

- male adult $\triangle$ female adult $\bigcirc$ male old $\Delta$ female old
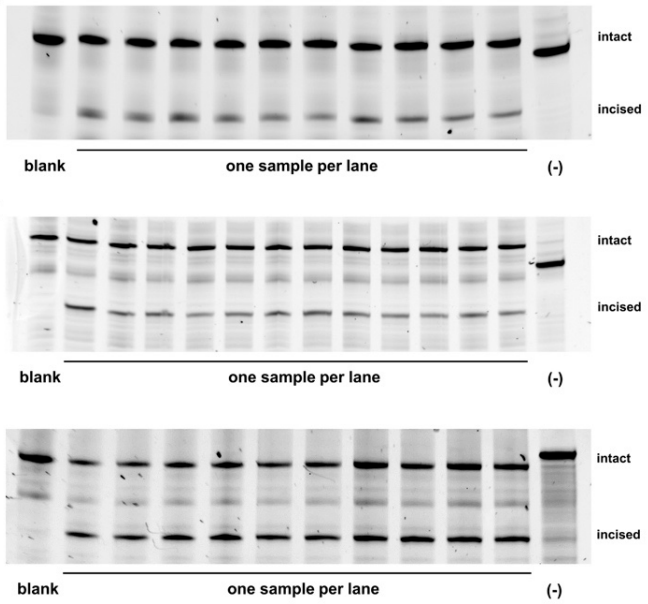

Figure 3. Impact of age and sex on incision activity. Shown is BER incision activity (individual single measurement scores per animal and group mean \pm SEM) of murine liver of adult (24 weeks, $n=10$ ) and old (109-114 weeks, $n=9$ ) animals of both sexes (female: $n=10$, male: $n=9)$ towards $(\mathbf{A}, \mathbf{D})$ the 8-oxodG, (B,E) the AP site analogue, and (C,F) the 5-OHdU containing oligonucleotide. Additionally, one representative polyacrylamide gel is shown for $(\mathbf{G})$ the 8 -oxodG, $(\mathbf{H})$ the AP site analogue, and $(\mathbf{I})$ the 5-OHdU containing oligonucleotide (full-length gels shown in Figure S3). The left lane shows the respective oligonucleotide blank followed by single sample measurements per lane and a negative control (as described above, marked as (-)) in the right lane. t-test, ${ }^{* *} p \leq 0.01$.

A

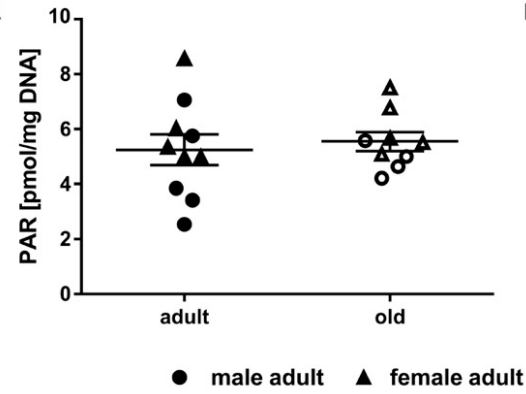

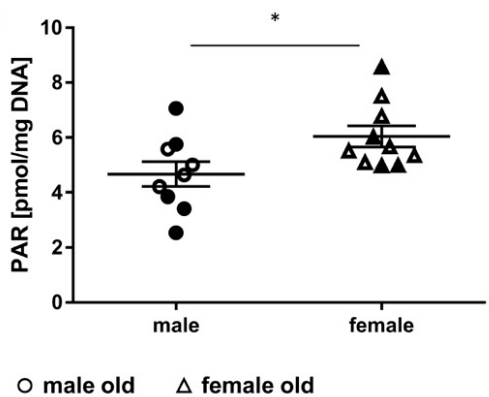

Figure 4. Impact of age and sex on PARylation. Shown are PARylation levels (individual single measurement scores per animal and group mean \pm SEM) of murine liver of adult (24 weeks, $n=10)$ and old (109-114 weeks, $n=9$ ) animals of both sexes (female: $n=10$, male: $n=9$ ). (A) adult versus old, (B) male versus female animals. t-test, ${ }^{*} p \leq 0.05$. 


\subsection{Assessment of DNA Damage in Murine Liver Samples}

The mouse livers showed no significant differences in mean DNA damage level between the groups of adult $(7.77 \pm 1.18 \%$ DNA in tail) and old animals $(8.63 \pm 1.55 \%$ DNA in tail) (Figure 5A). Yet, we found a significant difference in DNA damage between males and females (Figure 5B). Male animals $(10.61 \pm 0.93 \%$ DNA in tail) showed significantly increased mean levels in DNA damage compared to female animals ( $5.98 \pm 1.24 \%$ DNA in tail). In Figure A1E, results are shown differentiated for sex and age of the mice at the same time.

A

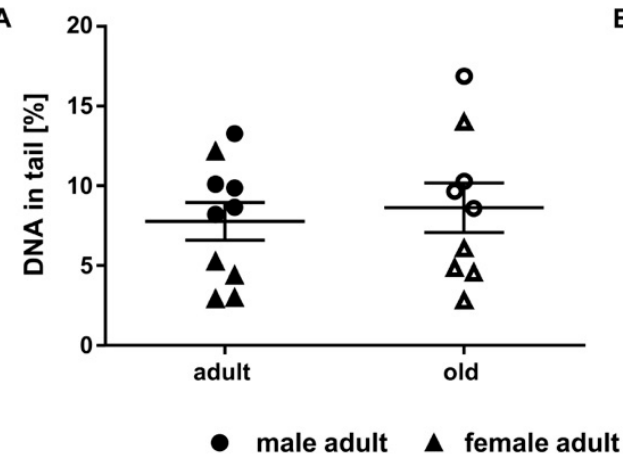

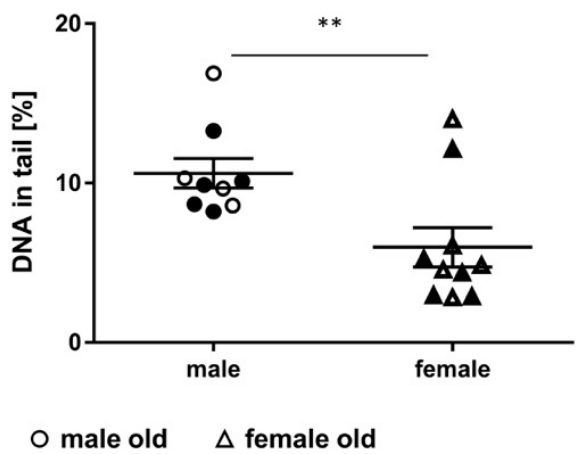

Figure 5. Impact of age and sex on DNA damage levels. Shown is DNA in tail (individual single measurement scores (two technical replicates) and group mean \pm SEM) of murine liver of adult (24 weeks, $n=10$ ) and old (109-114 weeks, $n=9$ ) animals of both sexes (female: $n=10$, male: $n=9$ ). (A) adult versus old, (B) male versus female animals. t-test, ${ }^{* *} p \leq 0.01$.

\subsection{Correlation of Genomic Stability Endpoints}

DNA damage and PARylation levels were inversely related $(p=0.002$, Spearman's $R=-0.658$; Figure 6A), while DNA damage levels and 5-OHdU incision activity were positively correlated $(p=0.003$, Spearman's $\mathrm{R}=0.651$; Figure $6 \mathrm{~B})$. A correlation matrix-based heat map including all results is shown in Figure 6C.

A

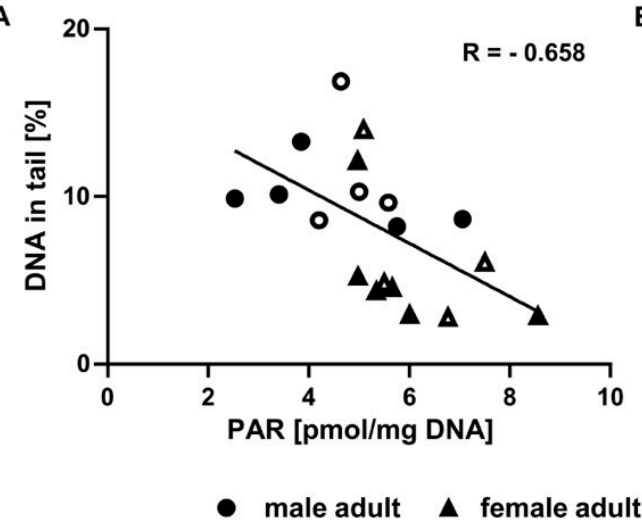

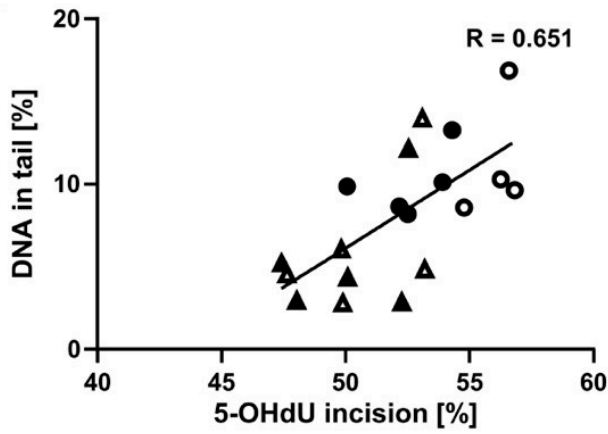

O male old $\Delta$ female old

Figure 6. Cont. 


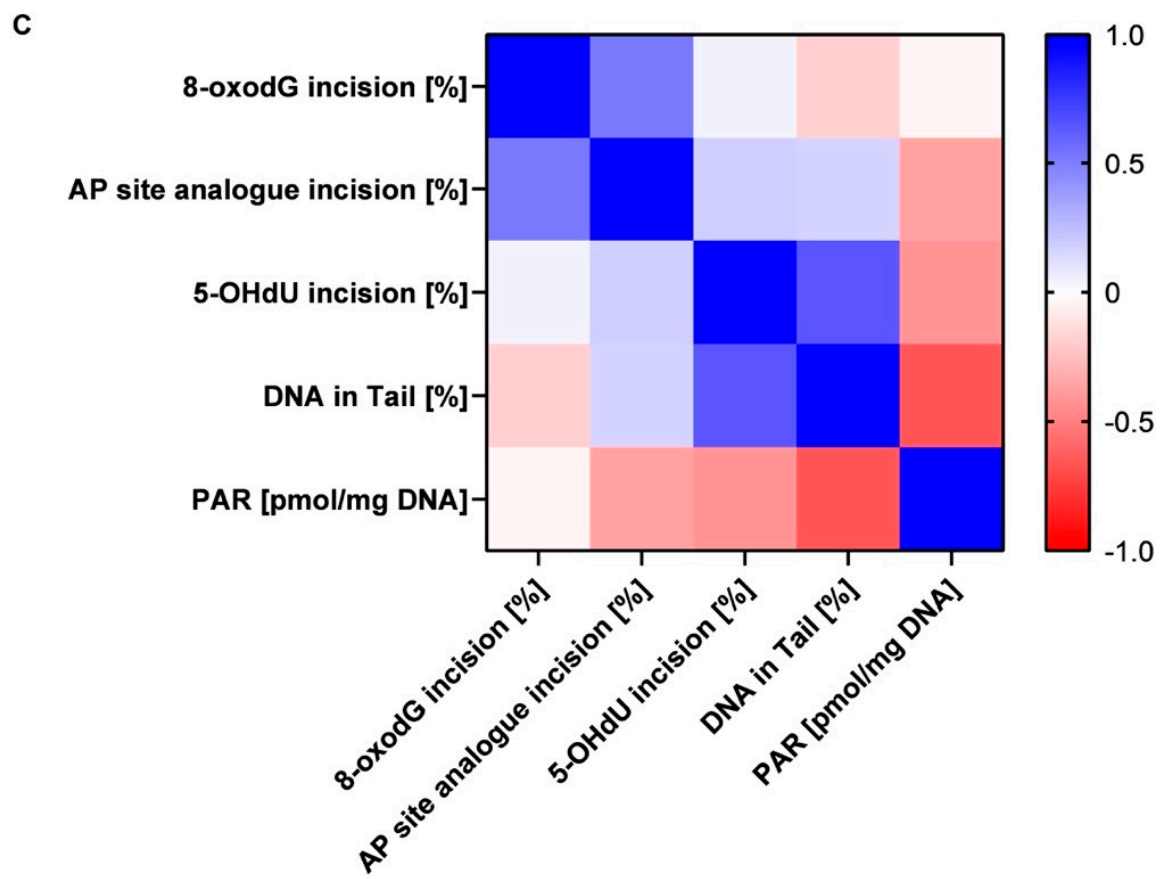

Figure 6. Relationships between genomic stability endpoints analysed by explorative correlation analysis. DNA damage and PARylation levels showed an inverse relationship (A) $(p=0.002$, Spearman's R = -0.658), while DNA damage levels and incision activity towards the 5-OHdU containing oligonucleotide were positively related $(\mathbf{B})(p=0.003$, Spearman's $\mathrm{R}=0.651)$. The black line represents the linear regression. The correlation matrix-based heat map indicates Spearman's correlation coefficient $R$ between the analysed genomic stability endpoints $(C)$.

\section{Discussion}

Within this study, we present a fluorescence-based, highly sensitive, reproducible, multi-endpoint incision activity assay to determine BER incision activity in tissue extracts from murine liver. The established protocol allows for simultaneously assessing incision activity towards three common DNA lesions proceeding from one single tissue extract, thereby saving time, effort, and animal derived tissue. In an ageing mouse cohort including animals of both sexes, we analysed BER incision activity, PARylation, and DNA damage levels in the liver. We have not performed analysis of specific tissue protein levels or quantity of the analysed DNA repair proteins, as it has been shown before that there is no relationship between the activity of DNA repair enzymes and mRNA or protein levels, respectively [45].

Our results for the incision activities towards different DNA lesions showed no significant age-related changes (Figure 3A-C). On the contrary, incision activities remained quite stable with increasing age. In the literature, this is controversially discussed. In rodent tissues, BER capacity has been reported to decrease [46,47] or increase [48], while others found a steady-state repair capacity [49]. In line with the latter, we found stable incision activities for both 8-oxodG, the AP site analogue, and 5-OHdU containing oligonucleotides independent of the age of the mice. In another study, for 8-oxodG, a significant age-related increase in damage levels (by $47 \%$ in liver) was observed in liver of old (24-26 months) compared to young ( 6 months) C57BL/6 mice. The authors also investigated the capacity of tissues from young and old mice to remove 8-oxodG after low-dose $\gamma$-irradiation. Interestingly, removal capacity for 8-oxodG did not strongly differ between young and old C57BL/6 mice, indicating a consistent DNA repair capacity with increasing age [49]. Further, Souza-Pinto and colleagues found a significant increase in mitochondrial repair capacity with increasing age, but nuclear incision activity was not affected [50]. In another study, APE1 protein and mRNA levels along with enzyme activity in total tissue extracts of mouse liver did not differ significantly between young ( 4 months), middle-aged 
(10 months), and old (20 months) mice. However, age-related differences in localisations of APE1 between nucleus, cytoplasm, and mitochondria were observed [51]. With the incision assay presented in this work, it is not possible to distinguish between nuclear or mitochondrial DNA repair capacity. Thus, we can assess overall capacity of the tissue to initialize BER and remove the respectively studied DNA lesions, which is, considering our results, not affected by age-related changes. In contrast, Gorniak and colleagues reported a two-fold increase in incision activity in livers from old (32 months) C57BL/6 mice compared to young mice ( 6 months) determined via comet-based incision assay [48]. This approach also targets the initial step of BER by using the photosensitiser Ro 19-8022 and visible light-damaged substrate cells that mainly contain 8-oxodG. It is surprising that the results the authors found are so contrary from what we observed. Besides the different attempts to measure BER incision activity, the studied mice, their age, and the tissue investigated were comparable. However, 5-OHdU incision activity also shows the tendency to increase with increasing age of the animals. This indicates a higher activity of the respective DNA glycosylases in old animals compared to the adult ones.

Besides BER incision activity, we quantified PARylation levels in the livers of the mice (Figure 4A). Although DNA repair is commonly studied in murine liver, PARylation levels have been investigated in a limited number of studies so far. PARylation levels showed no significant differences regarding the age of the animals. An important aspect to consider in this context is the dynamic interplay between BER coordinating enzymes and the redundancy of the BER system. The BER protein-protein interactions such as between OGG1 and PARP1 [52] as well as NEIL1 and PARP1 [53] impact on the enzymes' activities in multiple ways. Thus, incision activities towards 8-oxodG (mainly OGG1 activity) and towards 5-OHdU (mainly NTH1 and NEIL1/2 activity) as well as PARylation levels that show no age-related changes for each, could be interpreted as key players in a well-regulated overall BER system that is not affected by the animals' age. In line with this, damage levels assessed by alkaline comet assay were not affected by the age of the animals (Figure 5A). In general, it is assumed that the frequency of DNA damage increases in ageing [4]. Yet, various studies in humans showed contradictory results [54] that argue against the theory of DNA damage accumulation in ageing. Surprisingly, data evidently proving ageing as causally correlated with increasing DNA damage levels is scarce. In a mouse study with normally and prematurely aged mice, DNA damage was quantified by measuring inhibition of long-distance polymerase chain reaction. In liver tissue of inbred C57BL $/ 6$ mice (young $=4$ months old, old $=28$ months old) only a marginal increase in DNA damage was observed with increasing age. Surprisingly, DNA repair defective mice (ERCC excision repair $1^{-/ \Delta}$ and Ku 80 mutant mice, young $=5$ months old, old $=12$ months old) showed no increase in DNA damage in the liver with increasing age. Consequently, the authors conclude that neither normal nor premature ageing was associated with an increase in DNA damage [55]. These results rather support our findings of no increase in DNA damage in liver with ageing than the theory of DNA damage accumulation in ageing. This might indicate other cellular factors contributing to ageing. Nevertheless, by alkaline comet assay only single- and double-strand breaks, as well as alkali-labile sites are quantified [38]. Other ageing-associated DNA damage, such as DNA crosslinks and (oxidative) base modifications, are not taken into account $[2,5]$. In this context, Izzotti et al. revealed increased 8-oxodG as well as DNA crosslink levels associated with ageing in several mouse organs using highly sensitive LC-MS/MS techniques [56]. Hence, to avoid underestimation of DNA damage levels and to get a better understanding of the different occurring DNA damage types related to ageing, further studies are needed, including sensitive techniques to quantify several DNA damage types, such as LC-MS/MS-techniques [40].

To draw conclusions from the analysed endpoints, it is crucial to consider results holistically. Thus, exploratory correlation analysis revealed interesting interrelationships. We found a negative relationship between DNA damage and PARylation levels (Figure 6A). This seems contradictory to the observation that PARylation transiently increases in response to genotoxic insults and DNA damage $[33,34]$. Based on this, one would expect an increased PARylation in association with high damage levels, and so, a positive correlation. Yet, we cannot exclude that the overall damage level, 
including damage that was not assessed by alkaline comet assay, might be different from our results and hence the observed correlation might be distorted. However, it was also shown that PARylation of histones and the respective damage sites results in chromatin remodelling and relaxation of the chromatin structure. Resulting from this, accessibility of the damage site is improved and binding of DNA repair factors enhanced upon PARylation $[33,57]$. Thus, the negative relationship we observed could also reflect a repair facilitating effect of PARylation concomitant with decreasing DNA damage levels. In line with both discussed options, female mice showed moderately higher PARylation and distinctly lower DNA damage levels than male animals (Figures 4B and 5B). This could possibly be explained by considering that a significant increase in PARP1 activity in vitro was shown with factor ten increasing estradiol concentrations [58]. In general, female mice have estradiol concentrations ten times higher than males [59]. Thus, the observed sex-specific differences could be interpreted to follow the inverse relationship between PARylation and DNA damage levels.

Further, DNA damage levels were positively associated with 5-OHdU incision activity (Figure 6B). This indicates a causal relationship between low DNA damage levels and reduced activity of NEIL 1/2 and NTH1. Vice versa, increased DNA damage levels appear to enhance repair enzyme activity. Enhanced DNA repair enzyme activity at the same time results in an increased number of BER intermediates, in particular single-strand breaks. These further increase DNA damage levels as assessed by alkaline comet assay. In line with these findings, female mice showed lower DNA damage levels and lower 5-OHdU incision activity compared to the males (Figures $3 \mathrm{~F}$ and $5 \mathrm{~B}$ ).

Taken together, our results suggest that genomic stability maintaining and DNA damage reducing mechanisms in this study functioned more efficiently in female than in male mice.

However, our results also indicate that BER initiating enzyme activity might be affected by the DNA damage level and monitors the existing amount of DNA damage. Thus, quantification of the specific DNA lesions that are subject to the respective repair enzymes would be of interest. Moreover, monitoring of further enzymatic steps, such as gap-filling and termini clean-up by polymerases, in particular polymerase $\beta$ and the BER completing strand ligation step by ligases I and III $\alpha$ [60], would be required for additional validity regarding interpretation of results. Especially as the polymerase-mediated termini clean-up is indicated as the rate limiting step of BER [61], assessment of polymerase efficiency would add valuable information to this experimental setting. If by high fidelity of DNA glycosylases and APE1, many intermediate strand-breaks are generated, reduced polymerase activity could also result in strand-break accumulation and increased DNA damage levels as assessed by comet-assay analysis. Thus, aging could also affect enzymatic steps of BER aside from damage recognition and incision. Hence, an effect of aging on BER in this study cannot be excluded by the analysed endpoints.

Our results showed how the complex cellular mechanisms of DDR and DNA repair impact on each other, manifesting for example in an altered DNA damage status. Analysis of BER incision activity, PARylation status, and DNA damage levels can only give insights into the functionality of the cellular machinery maintaining genomic integrity. Yet, analysis of these endpoints can contribute to a deeper understanding of impacting factors such as sex and age on the cellular DNA damage defending mechanisms.

\section{Materials and Methods}

\subsection{Animal Husbandry}

Animal experiments were approved by and conducted following national guidelines of the Ministry of Environment, Health and Consumer Protection of the federal state of Brandenburg, Germany (2347-44-2017) and institutional guidelines of the German Institute of Human Nutrition Potsdam-Rehbruecke, Germany. Mice were housed in polycarbonate cages and kept under diurnal $12 \mathrm{~h} \mathrm{light/dark}$ cycles with light beginning at 6:30 AM; room temperature and humidity was kept constant at $22{ }^{\circ} \mathrm{C}$ and $55 \%$, respectively. Food (V1534, Ssniff, Soest, Germany) and water were offered ad libitum. 
Tissues were obtained from C57BL/6JRj mice of both sexes at an age of 24 (young adult, referred to as adult, 6 months) or 109-114 weeks (old adult, referred to as old, 28 months) anesthetised by isoflurane (Cp-pharma, Burgdorf, Germany), after blood withdrawal by heart puncture. Fresh liver tissue was cut in aliquots, snap-frozen in liquid nitrogen, and stored at $-80{ }^{\circ} \mathrm{C}$ until further use. All analyses were conducted with samples that were fully blinded starting from the point of tissue harvesting.

\subsection{Materials}

2-Amino-2-(hydroxymethyl)-1,3-propanediol (Tris), Tris hydrochloric acid ( $\mathrm{HCl})$, sodium chloride $(\mathrm{NaCl})$, sodium hydroxide $(\mathrm{NaOH})$, disodium ethylenediaminetetraacetate $\left(\mathrm{Na}_{2} \mathrm{EDTA}\right)$, acrylamide solution, urea, boric acid, $\mathrm{N}, \mathrm{N}, \mathrm{N}^{\prime}, \mathrm{N}^{\prime}$-tetramethylethylenediamine (TEMED), ammonium persulfate (APS), dimethyl sulfoxide (DMSO), methanol (MeOH), and normal melting point agarose were obtained from Roth (Karlsruhe, Germany). Acetylated bovine serum albumin (BSA), phenylmethanesulfonyl fluoride (PMSF), aprotinin, leupeptin, pepstatin, sodium fluoride (NaF), sodium orthovanadate $\left(\mathrm{Na}_{3} \mathrm{VO}_{4}\right)$, dithiothreitol (DTT), APC, bicinchoninic acid (BCA) solution, formamide, blue dextran, Triton X-100, low melting point agarose, 1,4-Diazabicyclo[2.2.2]octane, potassium chloride (KCl), and potassium phosphate $\left(\mathrm{KH}_{2} \mathrm{PO}_{4}\right)$ were obtained from Sigma/Merck (Darmstadt, Germany).

\subsection{Incision Activity Assay Principles}

This non-radioactive BER incision activity assay represents an advanced protocol based on the work of Hamann et al. [12]. We refined the scope of the assay from in vitro application for cultured cells to in vivo application for murine liver tissue samples. In addition, we broadened the assay spectrum to three oligonucleotides with different DNA lesions. This simplified the protocol and accelerated the tissue extract preparation. Also, it offered the possibility to study BER repair incision activity towards three common DNA lesions from a single tissue extract. In general, BER incision activity is studied by incubating Cy5-labelled hairpin-structured oligonucleotides incorporating different DNA lesions with a liver tissue extract that contains the damage incising repair enzymes. Hairpin-structure represents the more stable configuration compared to the frequently used duplex oligonucleotides [12]. The DNA lesions that proved successful incorporated into the oligonucleotides are the oxidative base modifications 8-oxodG and 5-OHdU [62], and an AP site analogue. Thus, repair enzyme-mediated processing of the DNA lesion leads to formation of a shorter, still fluorophore-labelled, oligonucleotide. Via a denaturing polyacrylamide gel electrophoresis (PAGE) the incised oligonucleotides were separated from the intact oligonucleotides, and subsequently quantified by fluorescence detection.

\subsection{Oligonucleotide Design}

Design of oligonucleotides was based on a previously suggested base sequence harbouring the DNA lesion 8-oxodG [12]. In addition, this base sequence was shown to be suitable for investigation of incision activity towards an AP site analogue (tetrahydrofuran (THF) derivate) [57]. THF is commonly applied to mimic an AP site in oligonucleotides [63]. Further, we aimed at investigating another oxidative base modification: 5-OHdU. To include 5-OHdU into the assay, a previously described base sequence of a 5-OHdU containing oligonucleotide was chosen as a point of reference regarding arrangement of the bases surrounding 5-OHdU [24]. By merging oligonucleotide base sequences, we created a new oligonucleotide with hairpin-feature and 5-OHdU as DNA damage. Examination of hybridization efficiency and storage stability showed satisfying stability of all hybridized oligonucleotides. Fluorescence-dye labelled oligonucleotides, containing either a DNA lesion or the respective intact DNA base, were obtained from Eurogentec (Seraing, Belgium). Regarding 8-oxodG and the AP site analogue, oligonucleotides consisted of the base sequence

5'-CAATAATAACACGCXCGACCAGTCCTGCTTTTGCAGGACTGGTCGCGCGTGTTATTATTGCy5-3' ( $X=8$-oxodG, AP site analogue). 
A further oligonucleotide with the identical base sequence, but with a $G$ instead of a DNA lesion, was used as damage-free negative control. For 5-OHdU and the respective damage-free oligonucleotide the base sequence was

5'-CAATAATAACTCGTXACTTCAGTCCTGCTTTTGCAGGACTGAAGTGACGACTTATTATTGCy5-3' (X = 5-OHdU or C).

Prior to use, oligonucleotides were hybridized to form a double-stranded hairpin structure by heating to $90{ }^{\circ} \mathrm{C}$ for $15 \mathrm{~min}$ followed by slowly cooling down to $30^{\circ} \mathrm{C}$ in $100 \mathrm{mM}$ Tris- $\mathrm{HCl}$ (pH 8), $10 \mathrm{mM}$ EDTA, and $50 \mathrm{mM} \mathrm{NaCl}$. Hybridized oligonucleotides were stored at $-20^{\circ} \mathrm{C}$ until use. For all oligonucleotides, hybridization efficiency, and storage stability were monitored by native PAGE.

\subsection{Preparation of Tissue Extracts for Incision Activity}

For preparation of tissue extracts, $1 \mathrm{~mL}$ of ice-cold extraction buffer $(50 \mathrm{mM}$ Tris- $\mathrm{HCl}$ (pH 7.1), $250 \mathrm{mM} \mathrm{NaCl}, 1 \mathrm{mM}$ EDTA, $0.5 \mathrm{mM}$ DTT, 20\% glycerol, $0.5 \mathrm{mM}$ PMSF, $10 \mu \mathrm{g} / \mathrm{mL}$ aprotinin, $5 \mu \mathrm{g} / \mathrm{mL}$ leupeptin, $1 \mu \mathrm{g} / \mathrm{mL}$ pepstatin, $50 \mathrm{mM} \mathrm{NaF}, 1 \mathrm{mM} \mathrm{Na}_{3} \mathrm{VO}_{4}, 1.5 \mu \mathrm{M}$ APC (1.5 $\mathrm{mM}$ in DMSO)) was added to $50 \mathrm{mg}$ of murine liver tissue. 30 zirconia beads (biolab, Bebensee, Germany) were added and the tissue was disrupted using a bead ruptor 12 (biolab, Bebensee, Germany). Tissue debris and beads were removed by centrifugation at $10,000 \mathrm{~g}$ and $4^{\circ} \mathrm{C}$ for $20 \mathrm{~min}$. The supernatant was collected and, for purification, centrifuged again. The protein content of the tissue extracts was determined via the BCA assay and the protein solutions were stored at $-80^{\circ} \mathrm{C}$.

\subsection{Incision Activity}

Reaction buffer, tissue extract, and hybridised oligonucleotide were mixed to a final reaction volume of $10 \mu \mathrm{L}$ containing $50 \mathrm{mM}$ Tris- $\mathrm{HCl}$ (pH 7.1), $50 \mathrm{mM} \mathrm{NaCl}, 0.1 \mu \mathrm{g} / \mu \mathrm{L}$ acetylated BSA, and $50 \mathrm{fmol}$ of oligonucleotide. After one-hour reaction time at $37^{\circ} \mathrm{C}$, the reaction was stopped by adding $10 \mu \mathrm{L}$ of denaturation buffer ( $90 \%$ formamide, $1 \mathrm{mM}$ EDTA ( $\mathrm{pH} 8$ ), $0.5 \%$ blue dextran), and heating to $95{ }^{\circ} \mathrm{C}$ for $5 \mathrm{~min}$. Additionally, for each determination an oligonucleotide blank and a negative control consisting of the respective damage-free oligonucleotide incubated with tissue extract were included in the assay. Then, a denaturing PAGE ( $20 \%$ denaturing polyacrylamide gel ( $7 \mathrm{M}$ urea, $89 \mathrm{mM}$ Tris-borate, $2 \mathrm{mM}$ EDTA (pH 8)), $2.5 \mathrm{~h}, 15 \mathrm{~W}$ per gel) followed to separate intact and incised oligonucleotides. For each animal, one tissue extract was prepared and one technical replicate was analysed for incision activity towards each of the three oligonucleotides. Detection and quantification of incision were conducted using a Chemidoc MP imaging system and the appropriate software Image Lab (Biorad, München, Germany).

\subsection{Analysis of PAR Levels}

We conducted the sample preparation according to a previously published [37,64] and adapted [65] method, but with an optimized application for murine liver tissue. To extract PAR, $1 \mathrm{~mL}$ ice-cold trichloroacetic acid (TCA) $(20 \%, \mathrm{w} / \mathrm{v})$ was added to $10-20 \mathrm{mg}$ of liver tissue. Tissue was disrupted using a tissue ruptor (Qiagen, Hilden, Germany) and subsequently centrifuged at $13,000 \mathrm{~g}$ and $4{ }^{\circ} \mathrm{C}$ for $15 \mathrm{~min}$. The resulting pellet was washed twice with ice-cold $70 \%$ ethanol (EtOH) and air-dried at $37^{\circ} \mathrm{C}$. To detach protein-bound PAR, $600 \mu \mathrm{L} 0.5 \mathrm{M}$ potassium hydroxide $(\mathrm{KOH})$ were added followed by thorough resuspension and incubation for $70 \mathrm{~min}$ at $37^{\circ} \mathrm{C}$. Tissue debris was separated by centrifugation at 13,000 $\mathrm{g}$ for $30 \mathrm{~min}$ and the supernatant was neutralized with $4.8 \mathrm{M} 3$-(N-morpholino)propanesulfonic acid (MOPS). $30 \mu \mathrm{L}$ aliquots were prepared for determination of DNA concentration to normalise results. DNA concentration was determined applying a previously described method based on the use of Hoechst [65].

Further sample treatment included the addition of ${ }^{13} \mathrm{C}_{1}^{15} \mathrm{~N}$-labelled PAR as internal standard, digestion of nucleic acids, enrichment, and digestion of PAR to its monomeric units. Last, PAR quantification was conducted via LC-MS/MS as described in detail by Neumann and colleagues [65]. 
For each animal, one tissue sample was prepared for PAR measurement and one technical replicate was measured via LC-MS/MS.

\subsection{Quantification of DNA Damage Levels}

Cells were isolated mechanically by pressing $40 \mathrm{mg}$ of snap frozen liver tissue through a cell strainer with $70 \mu \mathrm{m}$ mesh size moving a plunger up and down for several times [66]. Isolated cells were flushed with $2 \mathrm{~mL}$ Merchant's Medium $\left(0.14 \mathrm{M} \mathrm{NaCl}, 1.47 \mathrm{mM} \mathrm{KH}_{2} \mathrm{PO}_{4}, 2.7 \mathrm{mM} \mathrm{KCl}, 8.1 \mathrm{mM}\right.$ EDTA, $\mathrm{pH}$ 7.4) into a reaction tube below the strainer. Afterwards, the cell suspension was centrifuged at $100 \mathrm{~g}$ and $4{ }^{\circ} \mathrm{C}$ for $5 \mathrm{~min}$ and the supernatant was removed. $20 \mu \mathrm{L}$ of cell suspension containing $2 \times 10^{6}$ cells $/ \mathrm{mL}$ were mixed with $180 \mu \mathrm{L}$ of $0.5 \%$ low melting point agarose. $45 \mu \mathrm{L}$ of the mixture were placed on a with $1.5 \%$ of normal melting point agarose pre-coated slide, covered with a cover glass and kept at $4{ }^{\circ} \mathrm{C}$ to solidify. After cover glass removal, slides were kept in a lysis solution (0.1\% Triton X-100, 10\% DMSO, and $89.9 \%$ lysis buffer containing $10 \mathrm{mM}$ Tris, $2.5 \mathrm{M} \mathrm{NaCl}$, and $100 \mathrm{mM} \mathrm{Na} 2$ EDTA, $\mathrm{pH} 10$ ) for $1 \mathrm{~h}$ at $4^{\circ} \mathrm{C}$. After lysis, the slides were placed into an electrophoresis chamber filled with electrophoresis buffer ( $300 \mathrm{mM} \mathrm{NaOH}, 1 \mathrm{mM}$ EDTA, $\mathrm{pH} 13)$ to allow the DNA unwinding at $4{ }^{\circ} \mathrm{C}$. After 20 min of unwinding, electrophoresis was performed for 20 min at $25 \mathrm{~V}$, $300 \mathrm{~mA}$, and $4{ }^{\circ} \mathrm{C}$. The slides were neutralized by immersion with $0.4 \mathrm{M}$ Tris buffer (pH 7.5) for $5 \mathrm{~min}$ and were fixed for $5 \mathrm{~min}$ in ice-cold $\mathrm{MeOH}$. Slides were stained with $20 \mu \mathrm{L}$ of Gel red Nuclein Acid Gel Stain $\left(10,000 \times\right.$ in $\mathrm{H}_{2} \mathrm{O}$ Biotium, Hayward, CA, USA) prior to microscopy with a florescence microscope (Leica DM 2000 LED, Leica Microsystems GmbH, Wetzlar, Germany). For each treatment, 200 randomly selected cells (100 per technical replicate slide) for each treatment were analysed by the semi-automated image analysis software (Comet IV, Perceptive Instruments, Stone, UK). The mean of the medians of 100 comets per technical replicate was calculated for each animal [39]. The percentage of DNA in tail was used to quantify the DNA damage. For each animal, cells were isolated from one tissue sample and two technical replicates were analysed for DNA damage. To determine the day-to-day-variation and electrophoresis efficiency, human liver carcinoma (HepG2) cells were used as negative and MMS-treated HepG2 cells as positive control. Further information on storage stability is provided in Figure S2.

\subsection{Statistical Analysis}

Using GraphPad Prism 6 (version 6.01 for Windows, GraphPad Software, La Jolla, CA, USA), we tested for normal distribution using the Kolmogorov-Smirnov test. Because of the normal distribution of the data, two-tailed unpaired student's $t$-tests were performed for group-wise comparisons between the two age-groups and the two sex-groups. Next, exploratory correlation analysis applying Spearman's correlation was performed to assess the relationship between the analysed endpoints 8-oxodG, 5-OHdU, and AP site analogue incision activity, PARylation levels, and DNA damage levels. $p<0.05$ was regarded as statistically significant.

Supplementary Materials: Supplementary materials can be found at http://www.mdpi.com/1422-0067/21/18/ 6600/s1.

Author Contributions: Conceptualization, N W., V.K.W., K.L. and T.S.; data curation, N.W., V.K.W. and K.L.; formal analysis, N.W. and V.K.W.; funding acquisition, A.P.K. and T.S.; investigation, N.W., V.K.W., K.L. and M.M.; methodology, N.W., V.K.W., F.E., K.L., E.E.B., A.M., H.S., J.B. and T.S.; project administration, A.P.K. and T.S.; resources, A.P.K. and T.S.; supervision, T.S.; validation, N.W. and V.K.W.; visualization, N.W. and V.K.W.; writing—original draft, N.W., V.K.W. and T.S.; writing—review and editing, N.W., V.K.W., F.E., K.L., A.M., J.B., A.P.K. and T.S. All authors have read and agreed to the published version of the manuscript.

Funding: This research was funded by the German Research Foundation (DFG), DFG Research Unit FOR 2558, (FOR 2558, SCHW 903/16-1).

Acknowledgments: We thank Stephanie Homan for linguistic advice.

Conflicts of Interest: The authors declare no conflict of interest. 


\section{Abbreviations}

\begin{tabular}{|c|c|}
\hline 5-OHdU & 5-hydroxy-2'deoxyuracil \\
\hline 8-oxodG & 8-oxo-2'-deoxyguanosine \\
\hline $\mathrm{AP}$ & apurinic/apyrimidinic \\
\hline APC & aphidicolin \\
\hline APE & AP endonuclease \\
\hline APS & ammonium persulfate \\
\hline BCA & bicinchoninic acid \\
\hline BER & base excision repair \\
\hline BSA & bovine serum albumin \\
\hline CCD & charge-coupled device \\
\hline DDR & DNA damage response \\
\hline DMSO & dimethyl sulfoxide \\
\hline DTT & dithiothreitol \\
\hline $\mathrm{EtOH}$ & ethanol \\
\hline $\mathrm{HCl}$ & hydrochloric acid \\
\hline HEPES & 4-(2-hydroxyethyl)piperazine-1-ethanesulfonic acid \\
\hline $\mathrm{KCl}$ & potassium chloride \\
\hline $\mathrm{KH}_{2} \mathrm{PO}_{4}$ & potassium dihydrogen phosphate \\
\hline $\mathrm{KOH}$ & potassium hydroxide \\
\hline LC-MS/MS & liquid chromatography tandem mass spectrometry \\
\hline $\mathrm{MeOH}$ & methanol \\
\hline MOPS & 3-(N-morpholino)propanesulfonic acid \\
\hline $\mathrm{NaCl}$ & sodium chloride \\
\hline $\mathrm{Na}_{2}$ EDTA & disodium ethylenediaminetetraacetate \\
\hline $\mathrm{NaF}$ & sodium fluoride \\
\hline $\mathrm{NaOH}$ & sodium hydroxide \\
\hline $\mathrm{Na}_{3} \mathrm{VO}_{4}$ & sodium orthovanadate \\
\hline NEIL & Nei-like DNA glycosylase \\
\hline NTH & Nth-like DNA glycosylase \\
\hline OGG1 & 8-oxoguanine DNA glycosylase 1 \\
\hline PAGE & polyacrylamide gel electrophoresis \\
\hline PAR & poly(ADP-ribose) \\
\hline $\operatorname{PARP}(\mathrm{s})$ & poly(ADP-ribose) polymerase(s) \\
\hline PARylation & poly(ADP-ribosyl)ation \\
\hline PMSF & phenylmethanesulfonyl fluoride \\
\hline ROS & reactive oxygen species \\
\hline TCA & trichloroacetic acid \\
\hline TEMED & $\mathrm{N}, \mathrm{N}, \mathrm{N}^{\prime}, \mathrm{N}^{\prime}$-Tetramethylethylenediamine \\
\hline THF & tetrahydrofuran \\
\hline Tris & 2-amino-2-(hydroxymethyl)-1,3-propanediol \\
\hline
\end{tabular}




\section{Appendix A}

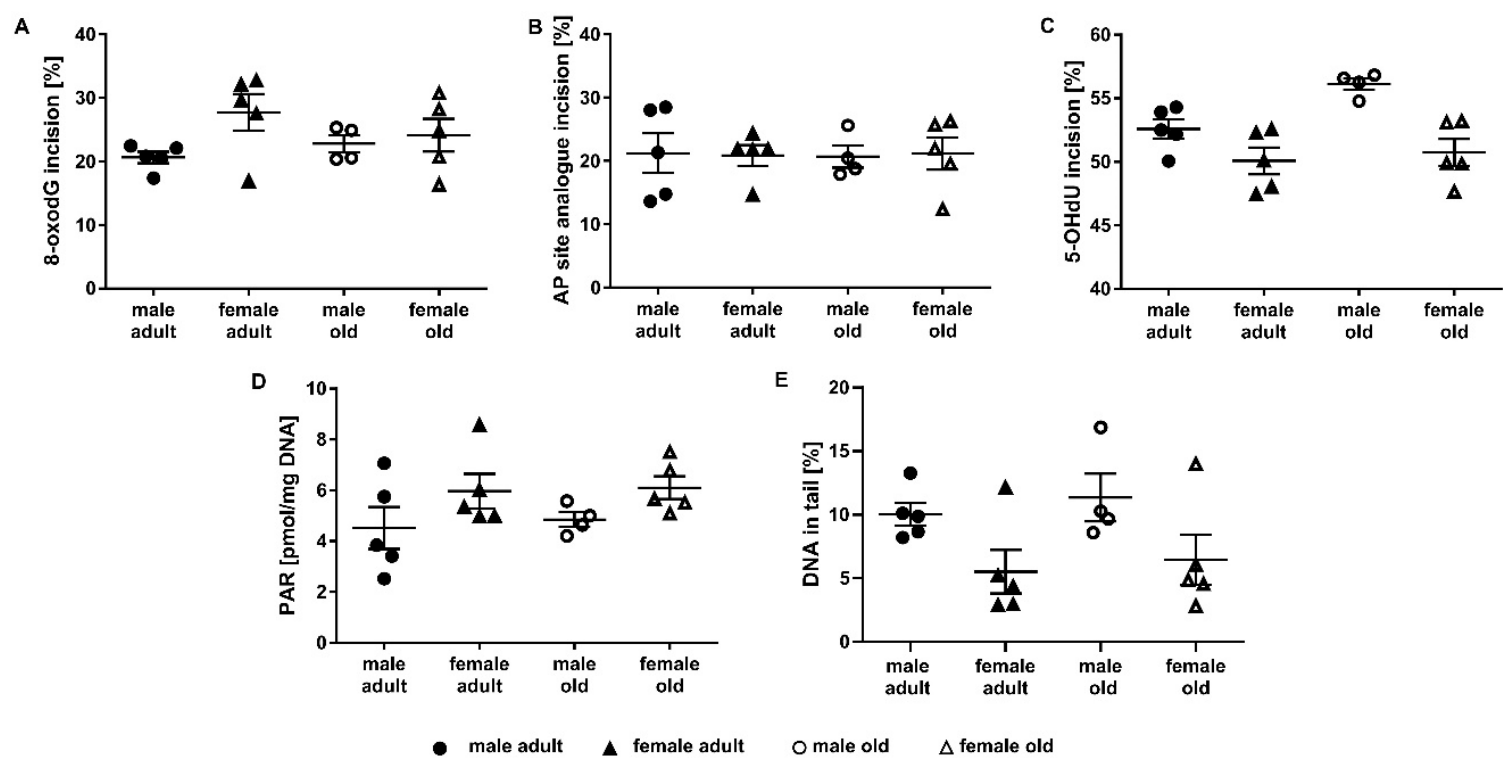

Figure A1. Impact of age and sex on incision activity, PARylation, and DNA damage levels. Shown is BER incision activity (individual single measurement scores per animal and group mean \pm SEM) of murine liver of adult (24 weeks, $n=10$ ) and old (109-114 weeks, $n=9$ ) animals of both sexes (female: $n=10$, male: $n=9$ ) towards (A) the 8-oxodG, (B) the AP site analogue, and (C) the 5-OHdU containing oligonucleotide. Additionally, shown are PARylation levels (individual single measurement scores per animal and group mean \pm SEM) (D) and DNA damage levels (individual single measurement scores (two technical replicates) and group mean \pm SEM) $(\mathbf{E})$.

\section{References}

1. Lindahl, T. Instability and decay of the primary structure of DNA. Nature 1993, 362, 709. [CrossRef]

2. Maynard, S.; Schurman, S.H.; Harboe, C.; de Souza-Pinto, N.C.; Bohr, V.A. Base excision repair of oxidative DNA damage and association with cancer and aging. Carcinogenesis 2009, 30, 2-10. [CrossRef] [PubMed]

3. López-Otín, C.; Blasco, M.A.; Partridge, L.; Serrano, M.; Kroemer, G. The hallmarks of aging. Cell 2013, 153, 1194-1217. [CrossRef]

4. Vermeij, W.P.; Hoeijmakers, J.H.J.; Pothof, J. Genome integrity in aging: Human syndromes, mouse models, and therapeutic options. Annu. Rev. Pharmacol. Toxicol. 2016, 56, 427-445. [CrossRef]

5. Niedernhofer, L.J.; Gurkar, A.U.; Wang, Y.; Vijg, J.; Hoeijmakers, J.H.J.; Robbins, P.D. Nuclear genomic instability and aging. Annu. Rev. Biochem. 2018, 87, 295-322. [CrossRef] [PubMed]

6. Bauer, N.C.; Corbett, A.H.; Doetsch, P.W. The current state of eukaryotic DNA base damage and repair. Nucleic Acids Res. 2015, 43, 10083-10101. [CrossRef]

7. Krokan, H.E.; Bjørås, M. Base excision repair. Cold Spring Harb. Perspect. Biol. 2013, 5, a012583. [CrossRef] [PubMed]

8. Wallace, S.S. Base excision repair: A critical player in many games. DNA Repair 2014, 19, 14-26. [CrossRef]

9. Whitaker, A.M.; Schaich, M.A.; Smith, M.R.; Flynn, T.S.; Freudenthal, B.D. Base excision repair of oxidative DNA damage: From mechanism to disease. Front. Biosci. 2017, 22, 1493-1522. [CrossRef]

10. Seeberg, E.; Eide, L.; Bjørås, M. The base excision repair pathway. Trends Biochem. Sci. 1995, 20, 391-397. [CrossRef]

11. Paz-Elizur, T.; Elinger, D.; Leitner-Dagan, Y.; Blumenstein, S.; Krupsky, M.; Berrebi, A.; Schechtman, E.; Livneh, Z. Development of an enzymatic DNA repair assay for molecular epidemiology studies: Distribution of OGG activity in healty individuals. DNA Repair 2007, 6, 45-60. [CrossRef] [PubMed]

12. Hamann, I.; Schwerdtle, T.; Hartwig, A. Establishment of a non-radioactive cleavage assay to assess the DNA repair capacity towards oxidatively damaged DNA in subcellular and cellular systems and the impact of copper. Mutat. Res. 2009, 669, 122-130. [CrossRef] [PubMed] 
13. Elliott, R.M.; Astley, S.B.; Southon, S.; Archer, D.B. Measurement of cellular repair activities for oxidative DNA damage. Free Radic. Biol. Med. 2000, 28, 1438-1446. [CrossRef]

14. Collins, A.R.; Fleming, I.M.; Gedik, C.M. In vitro repair of oxidative and ultraviolet-induced DNA damage in supercoiled nucleoid DNA by human cell extract. Biochim. Biophys. Acta 1994, 1219, 724-727. [CrossRef]

15. Parsons, J.L.; Dianov, G.L. In vitro base excision repair using mammalian cell extracts. In DNA Repair Protocols; Bjergbæk, L., Ed.; Humana Springer: Totowa, NJ, USA, 2012; pp. 245-262. ISBN 161779998X.

16. Golato, T.; Brenerman, B.; McNeill, D.R.; Li, J.; Sobol, R.W.; Wilson, D.M. Development of a cell-based assay for measuring base excision repair responses. Sci. Rep. 2017, 7, 13007. [CrossRef]

17. Chaim, I.A.; Nagel, Z.D.; Jordan, J.J.; Mazzucato, P.; Le Ngo, P.; Samson, L.D. In vivo measurements of interindividual differences in DNA glycosylases and APE1 activities. Proc. Natl. Acad. Sci. USA 2017, 114, E10379-E10388. [CrossRef]

18. Steenken, S.; Jovanovic, S.V. How Easily oxidizable is DNA? One-electron reduction potentials of adenosine and guanosine radicals in aqueous solution. J. Am. Chem. Soc. 1997, 119, 617-618. [CrossRef]

19. Klungland, A.; Rosewell, I.; Hollenbach, S.; Larsen, E.; Daly, G.; Epe, B.; Seeberg, E.; Lindahl, T.; Barnes, D.E. Accumulation of premutagenic DNA lesions in mice defective in removal of oxidative base damage. Proc. Natl. Acad. Sci. USA 1999, 96, 13300-13305. [CrossRef]

20. Bjorâs, M.; Luna, L.; Johnsen, B.; Hoff, E.; Haug, T.; Rognes, T.; Seeberg, E. Opposite base-dependent reactions of a human base excision repair enzyme on DNA containing 7,8-dihydro-8-oxoguanine and abasic sites. EMBO J. 1997, 16, 6314-6322. [CrossRef]

21. Dizdaroglu, M.; Holwitt, E.; Hagan, M.P.; Blakely, W.F. Formation of cytosine glycol and 5,6-dihydroxycytosine in deoxyribonucleic acid on treatment with osmium tetroxide. Biochem. J. 1986, 235, 531-536. [CrossRef]

22. Katafuchi, A.; Nakano, T.; Masaoka, A.; Terato, H.; Iwai, S.; Hanaoka, F.; Ide, H. Differential specificity of human and Escherichia coli endonuclease III and VIII homologues for oxidative base lesions. J. Biol. Chem. 2004, 279, 14464-14471. [CrossRef] [PubMed]

23. Wallace, S.S.; Bandaru, V.; Kathe, S.D.; Bond, J.P. The enigma of endonuclease VIII. DNA Repair 2003, 2, 441-453. [CrossRef]

24. Hazra, T.K.; Izumi, T.; Boldogh, I.; Imhoff, B.; Kow, Y.W.; Jaruga, P.; Dizdaroglu, M.; Mitra, S. Identification and characterization of a human DNA glycosylase for repair of modified bases in oxidatively damaged DNA. Proc. Natl. Acad. Sci. USA 2002, 99, 3523-3528. [CrossRef] [PubMed]

25. Dou, H.; Mitra, S.; Hazra, T.K. Repair of Oxidized Bases in DNA Bubble Structures by Human DNA Glycosylases NEIL1 and NEIL2. J. Biol. Chem. 2003, 278, 49679-49684. [CrossRef]

26. Bohr, V.A. Repair of oxidative DNA damage in nuclear and mitochondrial DNA, and some changes with aging in mammalian cells. Free Radic. Biol. Med. 2002, 32, 804-812. [CrossRef]

27. Robson, C.N.; Hickson, I.D. Isolation of cDNA clones encoding a human apurini/apyrimidinic endonuclease that corects DNA repair and mutagenisis defects in E.coli xth (exonuclease III) mutants. Nucleic Acids Res. 1991, 19, 5519-5523. [CrossRef]

28. Dizdaroglu, M. Oxidatively induced DNA damage and its repair in cancer. Mutat. Res. Rev. Mutat. Res. 2015, 763, 212-245. [CrossRef]

29. Brenerman, B.M.; Illuzzi, J.L.; Wilson, D.M. Base excision repair capacity in informing healthspan. Carcinogenesis 2014, 35, 2643-2652. [CrossRef]

30. Chaudhuri, A.R.; Nussenzweig, A. The multifaceted roles of PARP1 in DNA repair and chromatin remodelling. Nat. Rev. Mol. Cell Biol. 2017, 18, 610-621. [CrossRef]

31. Beneke, S.; Bürkle, A. Poly(ADP-ribosyl)ation, PARP, and aging. SAGE KE 2004, 2004, re9. [CrossRef]

32. Brochu, G.; Duchaine, C.; Thibeault, L.; Lagueux, J.; Shah, G.M.; Poirier, G.G. Mode of action of poly(ADP-ribose) glycohydrolase. Biochim. Biophys. Acta 1994, 1219, 342-350. [CrossRef]

33. Luo, X.; Kraus, W.L. On PAR with PARP: Cellular stress signaling through poly(ADP-ribose) and PARP-1. Genes Dev. 2012, 26, 417-432. [CrossRef] [PubMed]

34. Meyer, R.; Muller, M.; Beneke, S.; Kupper, J.H.; Burkle, A. Negative regulation of alkylation-induced sister-chromatid exchange by poly(ADP-ribose) polymerase-1 activity. Int. J. Cancer 2000, 88, 351-355. [CrossRef]

35. Beneke, S.; Bürkle, A. Poly(ADP-ribosyl)ation in mammalian ageing. Nucleic Acids Res. 2007, 35, 7456-7465. [CrossRef] 
36. Piskunova, T.S.; Yurova, M.N.; Ovsyannikov, A.I.; Semenchenko, A.V.; Zabezhinski, M.A.; Popovich, I.G.; Wang, Z.-Q.; Anisimov, V.N. Deficiency in poly(ADP-ribose) polymerase-1 (PARP-1) accelerates aging and spontaneous carcinogenesis in mice. Curr. Gerontol. Geriatr. Res. 2008, 2008. [CrossRef]

37. Martello, R.; Mangerich, A.; Sass, S.; Dedon, P.C.; Bürkle, A. Quantification of cellular poly(ADP-ribosyl)ation by stable isotope dilution mass spectrometry reveals tissue- and drug-dependent stress response dynamics. ACS Chem. Biol. 2013, 8, 1567-1575. [CrossRef]

38. Azqueta, A.; Collins, A.R. The essential comet assay: A comprehensive guide to measuring DNA damage and repair. Arch. Toxicol. 2013, 87, 949-968. [CrossRef]

39. OECD. Test No. 489: In Vivo Mammalian Alkaline Comet Assay, OECD Guidelines for the Testing of Chemicals, Section 4: Health Effects; OECD Publishing: Paris, France, 2016.

40. Yin, J.; Zhang, N.; Wang, H. Liquid chromatography- mass spectrometry for analysis of DNA damages induced by environmental exposure. TrAC Trends Anal. Chem. 2019, 120, 115645. [CrossRef]

41. Koley, D.; Bard, A.J. Triton X-100 concentration effects on membrane permeability of a single HeLa cell by scanning electrochemical microscopy (SECM). Proc. Natl. Acad. Sci. USA 2010, 107, 16783-16787. [CrossRef]

42. Langie, S.A.S.; Cameron, K.M.; Waldron, K.J.; Fletcher, K.P.R.; von Zglinicki, T.; Mathers, J.C. Measuring DNA repair incision activity of mouse tissue extracts towards singlet oxygen-induced DNA damage: A comet-based in vitro repair assay. Mutagenesis 2011, 26, 461-471. [CrossRef]

43. Coudore, F.; Calsou, P.; Salles, B. DNA repair activity in protein extracts from rat tissues. FEBS Lett. 1997, 414, 581-584. [CrossRef]

44. Salles, B.; Frit, P.; Provot, C.; Jaeg, J.-P.; Calsou, P. In vitro eukaryotic DNA excision repair assays: An overview. Biochimie 1995, 77, 796-802. [CrossRef]

45. Slyskova, J.; Langie, S.A.S.; Collins, A.R.; Vodicka, P. Functional evaluation of DNA repair in human biopsies and their relation to other cellular biomarkers. Front. Genet. 2014, 5, 116. [CrossRef] [PubMed]

46. Cabelof, D.C.; Raffoul, J.J.; Yanamadala, S.; Ganir, C.; Guo, Z.; Heydari, A.R. Attenuation of DNA polymerase $\beta$-dependent base excision repair and increased DMS-induced mutagenicity in aged mice. Mutat. Res. 2002, 500, 135-145. [CrossRef]

47. Swain, U.; Subba Rao, K. Study of DNA damage via the comet assay and base excision repair activities in rat brain neurons and astrocytes during aging. Mech. Ageing Dev. 2011, 132, 374-381. [CrossRef]

48. Gorniak, J.P.; Cameron, K.M.; Waldron, K.J.; von Zglinicki, T.; Mathers, J.C.; Langie, S.A.S. Tissue differences in BER-related incision activity and non-specific nuclease activity as measured by the comet assay. Mutagenesis 2013, 28, 673-681. [CrossRef]

49. Hamilton, M.L.; van Remmen, H.; Drake, J.A.; Yang, H.; Guo, Z.M.; Kewitt, K.; Walter, C.A.; Richardson, A. Does oxidative damage to DNA increase with age? Proc. Natl. Acad. Sci. USA 2001, 98, 10469-10474. [CrossRef]

50. De Souza-Pinto, N.; Hogue, B.A.; Bohr, V.A. DNA repair and aging in mouse liver: 8-oxoG glycosylase activity increase in mitochondrial but not in nuclear extracts. Free Radic. Biol. Med. 2001, 30, 916-923. [CrossRef]

51. Szczesny, B.; Mitra, S. Effect of aging on intracellular distribution of abasic (AP) endonuclease 1 in the mouse liver. Mech. Ageing Dev. 2005, 126, 1071-1078. [CrossRef]

52. Noren Hooten, N.; Kompaniez, K.; Barnes, J.; Lohani, A.; Evans, M.K. Poly(ADP-ribose) polymerase 1 (PARP-1) binds to 8-oxoguanine-DNA glycosylase (OGG1). J. Biol. Chem. 2011, 286, 44679-44690. [CrossRef]

53. Noren Hooten, N.; Fitzpatrick, M.; Kompaniez, K.; Jacob, K.D.; Moore, B.R.; Nagle, J.; Barnes, J.; Lohani, A.; Evans, M.K. Coordination of DNA repair by NEIL1 and PARP-1: A possible link to aging. Aging 2012, 4, 674-685. [CrossRef]

54. Jacob, K.D.; Noren Hooten, N.; Trzeciak, A.R.; Evans, M.K. Markers of oxidant stress that are clinically relevant in aging and age-related disease. Mech. Ageing Dev. 2013, 134, 139-157. [CrossRef] [PubMed]

55. Maslov, A.Y.; Ganapathi, S.; Westerhof, M.; Quispe-Tintaya, W.; White, R.R.; van Houten, B.; Reiling, E.; Dollé, M.E.T.; van Steeg, H.; Hasty, P.; et al. DNA damage in normally and prematurely aged mice. Aging Cell 2013, 12, 467-477. [CrossRef] [PubMed]

56. Izzotti, A.; Cartiglia, C.; Taningher, M.; de Flora, S.; Balansky, R. Age-related increases of 8-hydroxy-2'deoxyguanosine and DNA-protein crosslinks in mouse organs. Mutat. Res. 1999, 446, 215-223. [CrossRef]

57. Smith, R.; Lebeaupin, T.; Juhász, S.; Chapuis, C.; D’Augustin, O.; Dutertre, S.; Burkovics, P.; Biertümpfel, C.; Timinszky, G.; Huet, S. Poly(ADP-ribose)-dependent chromatin unfolding facilitates the association of DNA-binding proteins with DNA at sites of damage. Nucleic Acids Res. 2019, 47, 11250-11267. [CrossRef] 
58. Zhang, F.; Wang, Y.; Wang, L.; Luo, X.; Huang, K.; Wang, C.; Du, M.; Liu, F.; Luo, T.; Huang, D.; et al. Poly(ADP-ribose) polymerase 1 is a key regulator of estrogen receptor $\alpha$-dependent gene transcription. J. Biol. Chem. 2013, 288, 11348-11357. [CrossRef] [PubMed]

59. Nilsson, M.E.; Vandenput, L.; Tivesten, Å.; Norlén, A.-K.; Lagerquist, M.K.; Windahl, S.H.; Börjesson, A.E.; Farman, H.H.; Poutanen, M.; Benrick, A.; et al. Measurement of a comprehensive sex steroid profile in rodent serum by high-sensitive gas chromatography-tandem mass spectrometry. Endocrinology 2015, 156, 2492-2502. [CrossRef]

60. Beard, W.A.; Horton, J.K.; Prasad, R.; Wilson, S.H. Eukaryotic Base Excision Repair: New Approaches Shine Light on Mechanism. Annu. Rev. Biochem. 2019, 88, 137-162. [CrossRef]

61. Prasad, R.; Dianov, G.L.; Bohr, V.A.; Wilson, S.H. FEN1 stimulation of DNA polymerase beta mediates an excision step in mammalian long patch base excision repair. J. Biol. Chem. 2000, 275, 4460-4466. [CrossRef]

62. Dizdaroglu, M.; Bergtold, D.S. Characterization of free radical-induced base damage in DNA at biologically relevant levels. Anal. Biochem. 1986, 156, 182-188. [CrossRef]

63. Hamann, I.; König, C.; Richter, C.; Jahnke, G.; Hartwig, A. Impact of cadmium on hOGG1 and APE1 as a function of the cellular p53 status. Mutat. Res. 2011, 736, 56-63. [CrossRef] [PubMed]

64. Tulin, A.V. Poly(ADP-Ribose) Polymerase; Springer: New York, NY, USA, 2017.

65. Neumann, C.; Baesler, J.; Steffen, G.; Nicolai, M.M.; Zubel, T.; Aschner, M.; Bürkle, A.; Mangerich, A.; Schwerdtle, T.; Bornhorst, J. The role of poly(ADP-ribose) polymerases in manganese exposed Caenorhabditis elegans. J. Trace Elem. Med. Biol. 2019, 57, 21-27. [CrossRef] [PubMed]

66. Jackson, P.; Pedersen, L.M.; Kyjovska, Z.O.; Jacobsen, N.R.; Saber, A.T.; Hougaard, K.S.; Vogel, U.; Wallin, H. Validation of freezing tissues and cells for analysis of DNA strand break levels by comet assay. Mutagenesis 2013, 28, 699-707. [CrossRef] [PubMed]

(C) 2020 by the authors. Licensee MDPI, Basel, Switzerland. This article is an open access article distributed under the terms and conditions of the Creative Commons Attribution (CC BY) license (http://creativecommons.org/licenses/by/4.0/). 